\title{
Validity and Reliability Test of Work Climate Questionnaire and Quality of Work Life
}

\author{
Umi Salmah ${ }^{1}$, Harmein Nasution ${ }^{2}$, Gerry Silaban $^{3}$, and Etti Sudaryati ${ }^{4}$ \\ \{umisalmah@usu.ac.id $\left.{ }^{1}\right\}$ \\ Lecturer of Public Health Faculty and Doctoral Program Student of Public Health Faculty ${ }^{1}$, Lecturer of \\ Industrial Engineering Faculty ${ }^{2}$, Lecturer of Public Health Faculty University of Sumatera Utara ${ }^{34}$ \\ Medan, Indonesia
}

\begin{abstract}
Background: Test the validity and reliability of instruments research very much needed for accuracy data. The purpose of this research is to prepare a standardized questionnaire a standardized ready to be used for research about work climate and quality of work life. Climate Instruments work consists of roles and work responsibilities, environmental conditions work, benefits earned by workers, conflicts in the workplace, achievements achieved, employee loyalty, work risk taking, and clarity about the direction and goals of work. instruments Quality of life work tested taking into account health conditions and safety in the work, a sense of having a job, opportunity developing in the workplace perceived by workers, space work life, justice and equal rights at work, social suitability and life satisfaction of workers. Methods: Testing questionnaire work climate and the quality of working life conducted on a sample of 45 street sweepers in the City of Binjai. Testing the validity of the questionnaire was carried out using the Product technique Pearson moment while the reliability test is used with using the Alpha Technique Cronbach. Result: Validity test instrument against 167 question items shows that there is 126 question items were declared valid with more correlation values greater than 0.361 . While the reliability test of the climate question item work and quality of work life shows Alpha value Cronbach $>0.60$, then instrument the tested can be declared reliable or consistent. Conclusion: The results of the instrument test prove that the instrument has a value of validity and reliability fulfills to be used to measure the work climate questionnaire and quality of work life.
\end{abstract}

Keywords: quality of work life; work climate

\section{Introduction}

Quality of work life is very important to be a concern, because the quality of work life is closely related to other things, including how employee loyalty and satisfaction at work, a supportive work environment and how opportunities are created for employees to grow and develop according to their abilities and employees' commitment to the organization in which they work. Quality of work life on the side influence other factors in place work, quality of work life too influenced by various factors on among them is the atmosphere and conditions of the place work which is a dimension of climate work. This is found in several studies among them research, Noor and Adli, A [1], Karthick and Balaji [2], Hassan et al. [3], Badawy [4], can concluded that the quality dimension work life is influenced by factors such as compensation, job security and personal growth, opportunity to learn new things, compensation and 
complaints, decision-making process, work satisfaction work, the adequacy of financial needs, promotion system and welfare facilities, job involvement, freedom on the spot work, and welfare facilities.

Quality of work life is considered based on atmosphere and conducive working conditions so that workers feel that their physical needs such as food, shelter and clothing are met and psychological needs such as being satisfied, happy and respected in their workplace are also fulfilled. Research conducted by; Boudreau and Ramstad [5], Jannatin and Hadi [6], Wijaya [7], Masoud Birjandi [8], Putri [9], can concluded that there is influence and job satisfaction, productivity work, work performance, job performance, organizational support, organizational commitment on the quality of work life.

The working climate dimension, of course different in every business, depending on the industrial sector and its complex problems in the sector. According to Haslam et al, [10], can be concluded work climate is a perception about policies, practices and procedures perceived organizational accepted by individuals within organization, or individual perceptions against where he works. According to Streers [11], it can be concluded that the working climate is the basis for the workers to understand and interpret the environment and cultivate a relationship between rewards and sanctions.

According to Agustini [12], it can be concluded that the working climate can be measured by 9 factors that influence it. According to Steve Kelneer [13], Stinger [14], can conclude that the measurement of the working climate by using six dimensions. This study is a strengthening of new variables regarding the quality of work life based on the work climate of street sweeper workers. This study is a strengthening of new variables regarding the quality of work life based on the work climate of street sweeper workers.

The work climate consists of (1) work roles and responsibilities which include physical workloads and social mentality. (2) Work environment conditions, namely a safe and comfortable work environment including additional workloads, namely physical, chemical, biological, ergonomic and psychological factors. (3) Remuneration received by workers in the form of salaries, incentives, bonuses, allowances and participation in insurance. (4) Conflict in the workplace, namely the atmosphere in the workplace that can lead to helplessness of workers in relation to workers or workers with their jobs. (5) Performance in the job as a street sweeper. (6) Employee loyalty is manifested in the act of supporting hygiene efforts in Medan City. (7) Taking work risks related to perceptions, knowledge, training related to policies implemented by the Sanitation Office. 8. Clarity of direction and work objectives include descriptions and standard operating procedures for road sweeper workers.

The quality of work life studied in this research instrument also considers conditions of health and safety at work, a sense of belonging to a job, opportunities for development in the workplace that are felt by workers, work-life space, justice and equality at work, social suitability and life satisfaction of workers.

In measuring the working climate and quality of working life, standardized measuring instruments are needed, this is done to ensure the accuracy of the data to be collected. Measuring instruments that have a standard must meet the validity and reliability requirements. Measurement is a stage in determining the quality of the characteristics of the research subject or commonly known as variables. The questionnaire is a measuring tool used to measure an event used by researchers. A questionnaire can be called a collection of questions used to obtain information from someone related to the research to be carried out [15].

The questionnaire has an important role in determining the correctness of the data obtained in each study, the correctness of the data obtained is largely determined by the quality of the instruments used [16]. The questionnaire consists of several question items that are arranged 
with alternative answers that have been provided, so that selected respondents can provide answers according to the actual situation (Widi, [17]).

Testing the validity and reliability of the questionnaire used in this study aims to determine the extent to which a measuring instrument can be trusted in measuring something. In the validity test, there are three kinds of validity tests, namely the construct validity test, the criterion validity test, and the content validity test. The content validity test is a validity test that measures the extent to which an instrument research can accurately measure the variables that will be measured later. The construct validity test is a validity test that measures the extent to which a research instrument can measure the construct (the framework of a concept). The criterion validity test is a validity test that performs the test by comparing the research instrument with other research instruments that have been declared valid and reliable by correlating them. Where if the correlation value shows a significant value, then the instrument has validity criteria (Heale \& Twycross, [18].

The importance of the results of the validity and reliability tests of a research questionnaire can affect the data that researchers will get when conducting a study. The greater the value of the validity and reliability of an instrument, the more valid the data that will be obtained from a study will be more valid. Validity and reliability tests were carried out aimed at analyzing the work climate instruments and the quality of work life. Based on the description above, this study aims to prepare a standardized questionnaire ready to be used as a measuring tool for a study.

\section{Methodology}

To test the validity, the method used in this research is to use the questionnaire validity testing method for the quality of work life and work climate by using the Pearson Product Moment technique while the reliability test is used using the Alpha Technique Cronbach. Similarly did the Dewi and Sudaryanto [19] test for the validity of the questionnaire using the Pearson Product Moment technique while the reliability test was used using the Alpha Technique Cronbach.

\section{Population and Sample}

Population and sample used in testing questionnaires the work climate and quality of work life is quantitative research as many as 45 workers street sweepers in Binjai City by way given a questionnaire to be tested.

\section{Data Collection Technique}

Primary data for this type of quantitative research is obtained by direct interviews, which are guided by a semi-structured research questionnaire, that is, each structured statement ends the same with the same measuring instrument.

\section{Data Analysis Technique \\ Validity Test}

To find out the validity of an instrument (in the questionnaire), it is done by calculating the correlation between the r-count score of each question in a variable. To perform validity analysis, the Pearson product moment method can be used with the condition that the sample taken is normal $(\geq 30)$. If the calculated $r$-value $>r$ table $(r>0.361)$, the instrument used is said to be valid Singarimbun and Effendi [20]. 


\section{Reliability Test}

Reliability is a measure that shows the extent to which the measurement results remain consistent when two or more measurements are made of the same symptoms with the same measuring instrument. The question is said to be reliable if the respondent's answer to the question is consistent or stable over time. The reliability of the question items that have been declared valid in the validity test is determined by the following criteria:

If the value Cronbach's Alpha $>0.6$ then the question is reliable.

If the Cronbach's Alpha value < 0.6 then the question is not reliable Ghozali [21].

\section{Result and Discussion}

The results of the validity and reliability tests were carried out on 45 road sweepers in Binjai City. The test results can be seen in the table below:

Table 1. The results of the validity and reliability tests of the working climate variable

\begin{tabular}{lcccccc}
\hline $\begin{array}{l}\text { Working Climate } \\
\text { Variables }\end{array}$ & Df & $\begin{array}{l}\text { Alpha } \\
\text { Cron } \\
\text { Bach }\end{array}$ & r table & $\begin{array}{c}\text { Number of } \\
\text { questions }\end{array}$ & $\begin{array}{c}\text { Valid and } \\
\text { Reliable } \\
\text { amount }\end{array}$ & $\begin{array}{c}\text { Final } \\
\text { Number of } \\
\text { Questions }\end{array}$ \\
\hline $\begin{array}{l}\text { Work roles and } \\
\text { responsibilities } \\
\text { Trial (n=45) }\end{array}$ & 38 & 0,867 & 0,631 & 10 & 10 & 10 \\
\hline $\begin{array}{l}\text { Work Environment } \\
\text { Trial (n=45) }\end{array}$ & 38 & 0,854 & 0,631 & 6 & 6 & 6 \\
$\begin{array}{l}\text { Rewards } \\
\text { Trial (n=45) }\end{array}$ & 38 & 0,856 & 0,631 & 7 & 7 & 7 \\
$\begin{array}{l}\text { Conflicts at Work } \\
\text { Trial (n=45) }\end{array}$ & 38 & 0,787 & 0,631 & 6 & 6 & 6 \\
$\begin{array}{l}\text { Work Achievement } \\
\text { Trial (n=45) }\end{array}$ & 38 & 0,953 & 0,631 & 7 & 7 & 8 \\
\hline $\begin{array}{l}\text { Working Climate } \\
\text { Variables }\end{array}$ & Df & $\begin{array}{l}\text { Alpha } \\
\text { Cron }\end{array}$ & r table & $\begin{array}{c}\text { Number of } \\
\text { questions }\end{array}$ & $\begin{array}{c}\text { Number of } \\
\text { questions }\end{array}$ & $\begin{array}{c}\text { Number of } \\
\text { questions }\end{array}$ \\
\hline $\begin{array}{l}\text { Employee Loyalty } \\
\text { Trial (n=45) }\end{array}$ & 38 & 0,859 & 0,631 & 8 & 8 & 8 \\
$\begin{array}{l}\text { Job Risk Taking } \\
\text { Trial (n=45) } \\
\begin{array}{l}\text { Clarity of Direction } \\
\text { and Purpose of }\end{array}\end{array}$ & 38 & 0,912 & 0,631 & 8 & 8 & 7 \\
$\begin{array}{l}\text { Work } \\
\text { Trial (n=45) }\end{array}$ & 0,810 & 0,631 & 7 & 7 & \\
\hline
\end{tabular}

a. Test the validity and reliability Questionnaire questions regarding job roles and responsibilities 15 statements. After testing the test validity and reliability shows that as many as 10 questions have a value of $r$-count $>0.361$ (r-table) with a Cronbach's alpha value of 0.867 , it can be concluded that all questions on the role and work responsibility variables are valid and reliable. 
b. Test Validity and reliability Questionnaire questions about the conditions of the work environment 7 statements. After testing the test validity and reliability shows that as many as 6 questions have a value of $r$-count $>0.361$ ( $\mathrm{r}$-table) with a Cronbach's alpha value of 0.854 , it can be concluded that all questions on the variable working environment conditions are valid and reliable.

c. Test Validity and reliability Questionnaire questions regarding Rewards 10 statements. After testing the test validity and reliability shows that as many as 7 questions have a value of r-count> 0.361 (r-table) with a Cronbach's alpha value of 0.856 , it can be concluded that all questions of reward variables are valid and reliable.

d. Test Validity and reliability Questionnaire questions regarding conflict at work 11 statements. After testing the test validity and reliability shows that as many as 7 questions have a value of r-count> 0.361 (r-table) with a Cronbach's alpha value of 0.787 , it can be concluded that all conflict variable questions in the workplace are valid and reliable.

e. Test Validity and reliability Questionnaire questions about work performance 9 statements. After testing the test validity and reliability shows that as many as 7 questions have a value of r-count> 0.361 (r-table) with a Cronbach's alpha value of 0.953 , it can be concluded that all questions on the work performance variable are valid and reliable.

f. Test Validity and reliability Questionnaire questions regarding employee loyalty 9 statements. After testing the test validity and reliability shows that as many as 8 questions have a value of r-count> 0.361 (r-table) with a Cronbach's alpha value of 0.859 , it can be concluded that all questions on employee loyalty variables are valid and reliable.

g. Test Validity and reliability Questionnaire questions regarding occupational risk taking 10 statements. After testing the test validity and reliability shows that as many as 8 questions have a value of r-count> 0.361 (r-table) with a Cronbach's alpha value of 0.912 , it can be concluded that all questions on occupational risk-taking variables are valid and reliable.

h. Test Validity and reliability Questionnaire questions regarding clarity of direction and purpose of work 8 statements. After testing the test validity and reliability shows that as many as 7 questions have a value of r-count $>0.361$ (r-table) with a Cronbach's alpha value of 0.810 , it can be concluded that all questions on the variable of clarity of direction and work objectives are valid and reliable.

Table 2. The results of the validity and reliability of the instrument items of the quality of

\begin{tabular}{|c|c|c|c|c|c|c|}
\hline $\begin{array}{c}\text { Work climate } \\
\text { variable }\end{array}$ & Df & $\begin{array}{l}\text { Alpha } \\
\text { Cron } \\
\text { Bach } \\
\end{array}$ & $\begin{array}{c}\mathbf{r} \\
\text { table }\end{array}$ & $\begin{array}{c}\text { Number } \\
\text { of } \\
\text { questions }\end{array}$ & $\begin{array}{c}\text { The number } \\
\text { of valid and } \\
\text { reliable }\end{array}$ & $\begin{array}{c}\text { The final } \\
\text { number of } \\
\text { questions }\end{array}$ \\
\hline $\begin{array}{l}\text { K3 conditions Trials } \\
(\mathrm{n}=40)\end{array}$ & 38 & 0,886 & 0,631 & 9 & 9 & 9 \\
\hline $\begin{array}{l}\text { The feeling of } \\
\text { having a job } \\
\text { Trials }(n=40)\end{array}$ & 38 & 0,910 & 0,631 & 7 & 7 & 7 \\
\hline $\begin{array}{l}\text { opportunities to } \\
\text { develop at work } \\
\text { Trials }(n=40)\end{array}$ & 38 & 0,823 & 0,631 & 7 & 7 & 7 \\
\hline
\end{tabular}




\begin{tabular}{lcccccc} 
Work-life space & 38 & 0,824 & 0,631 & 7 & 7 & 7 \\
Trials (n=40) & & & & & & \\
\hline $\begin{array}{l}\text { Social suitability } \\
\begin{array}{l}\text { Trials (n=40) } \\
\text { Life satisfaction } \\
\text { Trials (n=40) }\end{array}\end{array}$ & 38 & 0,803 & 0,631 & 6 & 6 & 12 \\
\hline
\end{tabular}

a. Test of validity and reliability Questionnaire questions regarding occupational health and safety conditions 11 statements. After testing the test validity and reliability shows that as many as 9 questions have a value of r-count> 0.361 (r-table) with a Cronbach's alpha value of 0.886 , it can be concluded that all questions on the variables of occupational health and safety conditions are valid and reliable.

b. Test Validity and reliability Questionnaire questions about the feeling of having a job 10 statements. After testing the test validity and reliability shows that as many as 7 questions have a value of r-count $>0.361$ (r-table) with a Cronbach's alpha value of 0.910 , it can be concluded that all questions of the feeling variable have a valid and job reliability.

c. Test Validity and reliability Questionnaire questions regarding opportunities for development in the workplace 10 statements. After testing the test validity and reliability shows that as many as 7 questions have a value of r-count $>0.361$ (r-table) with a Cronbach's alpha value of 0.823 , it can be concluded that all questions on the opportunity to develop in the workplace are valid and reliable.

d. Test Validity and reliability Questionnaire questions regarding work-life space 8 statements. After testing the test validity and reliability shows that as many as 7 questions have a value of r-count> 0.361 (r-table) with a Cronbach's alpha value of 0.824 , so it can be concluded that all questions on work-life variables are valid and reliable.

e. Test Validity and reliability Questionnaire questions on justice and equality at work 8 statements. After testing the test validity and reliability shows that as many as 5 questions have a value of r-count> 0.361 (r-table) with a Cronbach's alpha value of 0.874 , it can be concluded that all questions on the variables of justice and equality of rights in the workplace are valid and reliable.

f. Test Validity and reliability Questionnaire questions about social suitability 8 statements. After testing the test validity and reliability shows that as many as 6 questions have a value of r-count> 0.361 (r-table) with a Cronbach's alpha value of 0.803 , it can be concluded that all questions on social suitability variables are valid and reliable.

g. Test Validity and reliability Questionnaire questions regarding life satisfaction 15 statements. After testing the test validity and reliability shows that as many as 12 questions have a value of r-count> 0.361 (r-table) with a Cronbach's alpha value of 0.837 , it can be concluded that all questions on life satisfaction variables are valid and reliable.

h. The results of previous studies on the validity and reliability of work-life quality instruments conducted by Wartini and Yusuf (2016) [22]., of the 9 question items, there are 5 valid items that have a value of rcount $>$ rtable ( 0.3$)$. Cronbach's Alpha exceeds 0.60 which is 0.682 so the instrument is reliable. 
The results of previous studies on the validity and reliability of work climate instruments conducted by Rahsel, Y. (2016) [23] contained 15 items of work climate, Cronbach's alpha value of the work climate variable was 0.747 .

\section{Conclusion}

Based on the questionnaire trials that have been conducted by researchers using 45 street sweeper workers in Binjai City as the subject of the validity and reliability tests, the results show that the validity test on questions about the work climate is obtained to have a calculated value. $>0.361$ :

Questions about roles and responsibilities get 10 questions. Validity test on questions regarding the conditions of the work environment obtained 6 questions. Validity test on questions regarding Rewards obtained 7 questions. The validity test on questions regarding conflict obtained 7 questions. Validity test on questions regarding work performance obtained 7 questions. Validity test on questions regarding employee loyalty obtained 8 questions. Validity test on questions regarding occupational risk taking, obtained 8 questions. Validity test on questions regarding the clarity of direction and work objectives obtained 7 questions.

The results of the validity test on the quality of work life variable obtained a value of $r$ count $>0.361$ which was declared valid: 9 questions regarding health and safety conditions were obtained. The validity test on questions about the feeling of having a job found 7 questions. Validity test on questions regarding opportunities to develop in the workplace obtained 7 questions. The validity test of the work-life space questions obtained 7 questions. The validity test on questions about justice and equality in the workplace obtained 5 questions. Social suitability obtained 6 questions. Validity test on questions about life satisfaction obtained 12 valid questions.

In the reliability test of the work climate variable regarding roles and responsibilities, the value was Cronbach's alpha 0.867 . In the working environment, the value of Cronbach's alpha is 0.854 . On the question of reward, Cronbach's alpha value was 0.856 . On the question about conflict in the workplace, Cronbach's alpha value was 0.787 . On the question regarding work performance, the Cronbach's alpha value was 0.953 . In the question regarding employee loyalty, the Cronbach's alpha value was 0.859 . In the question regarding occupational risk taking, the Cronbach's alpha value was 0.912 . In the question regarding the clarity of direction and work objectives, Cronbach's alpha value was 0.810 .

In the reliability test of the quality of work life variable regarding the question of health and conditions, occupational safety the Cronbach's alpha value was 0.886 . In the question about the feeling of having a job, the Cronbach's alpha value was 0.910 . On the question of opportunities for development in the workplace, Cronbach's alpha value was 0.823 . In the question about work-life space, Cronbach's alpha value was 0.824 . On the question of justice and equality of rights at work, Cronbach's alpha value was 0.874 . On the question of social suitability, the Cronbach's alpha value was 0.803 . On the question of life satisfaction, the Cronbach's alpha value was 0.837 .

From the results of the validity and reliability trials above, it means that the list of questions is declared valid and consistent. Relevant needs and perceptions regarding the concept of work life may vary according to the organization and characteristics of the job. Factors that affect the quality of work life differ from one another to each job and this instrument can be used as a tool to measure the quality of work life in similar fields in the future so that it can strengthen theories 
about the work climate and the quality of work life. This instrument can measure the quality of work life in the study of occupational health and safety sciences in informal sector workers.

\section{Acknowledgments}

Thank you for the support provided by the University of North Sumatra and the Faculty of Public Health, the Environmental Service (DLH) for the permit granted and road sweeper workers in Binjai City who are willing to be respondents in this questionnaire trial.

\section{References}

[1] Noor S., \& Adli, A. (2011). Quality work life among faktory workers in Malaysia Procedia - Social and Behavioral Sciences 35 ( 2012 ) 739 - 745, 35, 739-745

[2] Karthick, S., \& Balaji, V. (2014). Faktors affecting quality of work life: An analysis on Employees of Private Banks. International Journal of Exclusive Management Research (IJEMR), 4. Diakses dari http://connection.ebscohost.com/c/articles/97438616/faktors-affecting-quality-work-life-analysisemployees-private-banks

[3] Hassan, N., Maa'amor, H., Razak, A., Norfadzillah, \& Lapok, F. (2013). The effect of quality of worklife (qwl) program on quality of life (qol) among employees at multinational companies in Malaysia. Procedia-Social and Behavior Science,, 24-34.

[4] Badawy, T. A. E. (2016). World Journal of Bisnis dan Manajemen, 2 No. 2. https://www.researchgate.net/publication/309273060_The_Quality_of_Work_Life_in_Egypt.

[5] Boudreau, J.W. \& Ramstad, P.M. (2007). Beyond HR: the new science of human capital. Boston: Harvard Business School Press.

[6] Jannatin, M., Kirana, \& Hadi, C. (2012). Pengaruh kualitas kehidupan kerja (quality of work life) terhadap produktivitas karyawan produksi. Jurnal Psikologi Industri dan Organisasi, 1(2). Diakses dari http://www.journal.unair.ac.id/filerPDF/jpioef2bd38bbb2full.pdf.

[7] Wijaya, D., Adi (2013). Peran dukungan organisasi, kepuasan kerja \& Kualitas kehidupan kerja terhadap komitmen organisasi efektif karyawan. Universitas Gadjah Mada Yogyakarta. Diakses dari http://etd.repository.ugm.ac.id/index.php?mod=penelitian_detail\&sub=PenelitianDetail\&act=view \&typ=html\&buku_id=59958.

[8] Masoud., B., Hamid, B., \& Ataei, M. (2013). The relationship between the quality of work life and organizational commitment of the employees of Darab cement company : case study in Iran. International Journal of Economics, Business and Finance, 1. Diakses dari http://www.ijebf.com/IJEBF_Vol.\%201,\%20No.\%207,\%20August\%20 202013/The\%20relationship\%20between.pdf

[9] Putri, R., Cintya (2014). Hubungan antara kualitas kehidupan kerja dangan komitmen organisasi pada pegawai negeri sipil di biro keuangan dan BMN Kementerian Kesehatan. Diakses dari http://etd.repository.ugm.ac.id/index.php?mod=penelitian_detail\&sub=PenelitianDetail\&act=view \&typ=html\&buku_id=79121.

[10] Haslam, S. A., Reicher, S. D., \& Platow, M. J. (2010). The New Psychology of Leadership: Identity, Influence \& Power. NY: Psychology Press.

[11] Streers, R. M. (2005). Efektivitas organisasi (terjemahan). Jakarta: Erlangga.

[12] Agustini, Fauziah. (2010) ManajemenSumber Daya ManusiaLanjutan. Medan. Mandenatera

[13] Kelner, S. (1998). Managing the climate of a TQM organization journal center for quality of management, volume 7, Number 1

[14] Stinger, R. (2002). Leadership and organitational climate: the cloud chamber effect. . Saddle River.NJ: Prentice Hall.

[15] Sugiyono. (2013). Metode Penelitian Kuantitatif, Kualitatif dan R\&D. Bandung: Alfabeta.

[16] Nuryani. (2019). Validity and Reliability Questionnaire of Knowledge , Attitude and Practice of Balanced Diet among Adolescent. Gizi Dan Kesehatan, 3(2), 37- 46. 
[17] Widi, R. (2011). Uji Validitas dan Reliabilitas dalam Penelitian Epidemiologi Kedokteran Gigi. Stomatognatic (J.K.G. Unej), 8(1), 27-34.

[18] Heale, R., \& Twycross, A. (2015). Validity and reliability in quantitative studies. EvidenceBased Nursing, 18(3), 66-67. https://doi.org/10.1136/eb-2015-102129

[19] Dewi, S. K., \& Sudaryanto, A. (2020). Validitas dan Reliabilitas Kuesioner Pengetahuan, Sikap, dan Perilaku Pencegahan Demam Berdarah. Prosiding Seminar Nasional Keperawatan Universitas Muhammadiyah Surakarta. E-ISSN: 2715-616X.

[20] Singarimbun, M. \& Effendi, S. (2011). Metode penelitian survei. Jakarta: PT Pustaka LP3ES.

[21] Ghozali, Imam. 2011. Aplikasi Analisis Multivariate dengan Program SPSS Cetakan IV. Semarang; Badan Penerbitan Universitas Diponegoro.

[22] Setiyadi.Y.W.,Wartini.s.,(2016).Pengaruh kualitas kehidupan kerja terhadap kinerja karyawan dengan kepuasan kerja sebagai variabel intervening. Management Analysis Journal 5 (4) diakses dari file:///D:/Documents/Downloads/12306-Article\%20Text-28391-1-10-20170425.pdf

[23] Rahsel, Y. (2016) Pengaruh iklim kerja terhadap kinerja pegawai administrasi pusat Universitas Padjadjaran Bandung (Studi Pada Bagian Administrasi Umum UNPAD). Jurnal Manajemen Magister, Vol 02. No.01, diakses dari https://media.neliti.com/media/publications/209576-pengaruhiklim-kerja-terhadap-kinerja-pe.pdf 